JOURNAL OF SECURITY AND SUSTAINABILITY ISSUES ISSN 2029-7017 print/ISSN 2029-7025 online 2019 June Volume 8 Number 4 http://doi.org/10.9770/jssi.2019.8.4(6)

Scopus ${ }^{\circ}$

\title{
COMMUNICATION EFFICIENCY AND EFFECTIVENESS WITHIN STRATEGIC MANAGEMENT OF CHANGE: INSIGHTS INTO CIVIL SERVICE ORGANIZATIONS
}

\author{
Mindaugas Laužikas', Aistė Miliūtè \\ ${ }^{1}$ Vilnius University Business School, Saulètekio Av. 22, LT-10225 Vilnius, Lithuania \\ ${ }^{1}$ Global Innovation Learning Ecosystem (GILE) Experts, Corradino Industrial Estate, Paola, Malta \\ ${ }^{2}$ Vilnius University Business School, Saulètekio Av. 22, LT-10225 Vilnius, Lithuania \\ JSC AKVAVITA, Neravu st. 100, Viečiünai, Lithuania

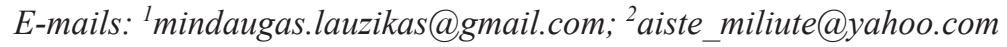

Received 21 February 2019; accepted 15 August 2019; published 30 June 2019

\begin{abstract}
In spite of relatively well-established literature on efficiency and effectiveness (Mouzas, 2006; Guisso et al, 2003; Saruliene and Vilkas, 2011; Ribeiro-Soriano, 2017; and etc.) and on communication efficiency and effectiveness (Hovland, 2005; Macnamara, 2016; Ferguson et al, 2016; and etc.), the scarcity of literature with concrete recommendations related to communication in civil service organizations during the time of change makes this topic relevant and value-adding to economies that undergo major reforms and transformation. Civil service systems (including communication models) differ from one category of countries to another. While innovation-driven economies, such as the UK, the USA, Australia, Canada, are clear leaders in terms of communication efficiency in civil service organizations (actively applying modern technologies and Government to Citizen model), efficiency-driven economies, such as Lithuania, Croatia, Georgia and Malta, are still focusing on development of efficient communication systems (via modern technologies, innovation processes, and stronger co-operation with stakeholders). This topic becomes even more relevant in status and hierarchydriven organizations. The research question is how to enhance communication efficiency within civil service organizations of tall hierarchy and create bigger value-added to society during the time of change. The publication is relevant to Lithuania and other CEEC countries, due to fast transformation of their economies. Moreover, the role of emerging new technologies should be acknowledged, as communication becomes more transformational, interactive and co-operation-driven. Efficiency-driven economies are experiencing continuous improvement of management processes; thus, they need to address many communication-related challenges, such as: how to engage society and build community, how to reach synergy effect among stakeholders, or how to apply modern technologies and interactive communication tools when social trust is insufficient. The present research is based on combination of scientific literature analysis and semi-structured expert interviews with 20 specialists of Lithuanian civil service organizations. The communication efficiency matrix in civil service organizations is developed, while summarizing research and scientific literature analysis results. The case of Lithuanian civil service organizations and the provided recommendations will serve as a useful tool among experts of policy-making, governmental programs or within strategy development and execution area in public administration organizations.
\end{abstract}

Keywords: communication efficiency and effectiveness; time of change; hierarchy; civil service organizations

Reference to this paper should be made as follows: Laužikas, M.; Miliūtè, A. 2019. Communication Efficiency and Effectiveness within Strategic Management of Change: Hierarchy and Strategy Development in Lithuanian Civil Service Organizations, Journal of Security and Sustainability Issues, 8(4): 617-630. http://doi.org/10.9770/jssi.2019.8.4(6)

JEL Classification: M130

\section{Introduction}

The communication efficiency throughout various literature sources is analysed from very diverse angles and within different contexts. Husain (2013) emphasized the role of employees as a key trigger to the change in organizations: job security should be established in order to create a sense of community. Shanga et al. (2017) focused on strategies to improve communication efficiency between nurses and physicians, while addressing 
different communication tools, team training, multidisciplinary structured work shift evaluation or electronic documentation templates. Luthra and Dahiya (2015) emphasized the role of leadership (more precisely, how leadership is affected by communication); while McEwan et al (2017) examined attempts of improving teamwork and the team performance via team interventions. Moreover, very useful insights might be found in Abroms's and Maibach's (2008) works, while accentuating the effectiveness of mass communication to change public behaviour.

The literature on communication efficiency and effectiveness is often of more generic nature, while abundance of scientific sources related to efficiency and effectiveness (see the chapter on effectiveness and efficiency) does not reveal a full spectrum of communication aspects referred to civil service organizations during the time of change: concrete cases of improvement in communication efficiency and effectiveness within various economies are necessary. For instance, according to Shegenovna (2014), professionalism of public service employee plaid important role in modernization processes in Kazakhstan, while Olufemi (2012) drew attention to the role of computer use on efficiency of civil servants' performance, which corresponded more to the context of factors-driven economies.

While focusing on the case of Ethiopia, Kassa (2011) concludes that efficient governance and civil service reform should have competency communication strategy along with strong monitoring and efficiency/ effectiveness evaluation system among other conditions, such as clear roadmaps, political leadership commitment, capacity development programmes, and contextualisation. Bhatnagar (2014) discussed the use of information and communication technology for improving governance in the delivery of services to the poor. All these publications illustrate the attempts to transform factors or efficiency-driven economies to higher category; therefore, the positive experience of innovation-driven countries, such as the UK Government Communication Plan 2017/2018, is critical to develop a sustainable policy and strategy among civil service organizations in catching-up economies.

Communication efficiency and effectiveness are multi-facet terms covering a set of dimensions, such as internal and external communication, communication impacts, as well as horizontal/ vertical and networksdriven communication. Communication affects success of various organizations via innovative communication technologies, communication optimization techniques, and many other instruments.

According to Vozab (2012), who focused on Croatian civil service organizations, it is difficult to communicate the information efficiently in order to not lose strategic content, to strengthen social trust and organizational image within society as well as to cut information asymmetry while satisfying all stakeholders. Communication models vary from one organization to another, depending on juridical status, lifetime, management style, experience, hierarchy, strategy, and many others aspects. According to Paynton et al (2016), linear and transactional communication types are combined in many organizations, but modern technologies make communication more intuitive, interactive and improvisation-based. Thus, communication in modern organizations is more transformational, influencing attitude and perception of society, employees and other stakeholders.

The added value is related not only to economic impacts and financial results; non-financial motivation via engagement of employees and society could also play a critical role, while too rigid performance optimizationoriented communication could endanger creativity system and creative leadership (French, 2017; Borisov et al., 2018; Lorincová et al., 2019; Laužikas, Miliūtė, 2019).

Given the specificity of internal communication, efficiency incorporates many different aspects, such as employee motivation and productivity, creativity, flexibility, quality and leadership. Moreover, on the side of external communication, a set of factors should be emphasized, such as: social image, society engagement and trust, community building, feasibility of strategic tasks, partnership, sustainability, economic and social impacts, and many others. Hierarchy type (tall or flat), which is dominant in an organization because of a set of factors (such as power distance, management style, juridical status, level of creativity and bureaucracy) affects the communication style and communication techniques, but efficiency can be present in all types of organizations, if necessary, actions are taken. 


\section{Effectiveness versus Efficiency}

The terms effectiveness and efficiency are in general compared in the context of business dynamics; it can be tackled from a more generic perspective of organization performance or investigated in a particular area, such as Human Resource Strategy, innovation performance or communication models. In spite of being tightly related, based on Mouzas (2006), the concept of efficiency differs from the concept of effectiveness. Both terms measure the performance of organisations; they are applied to business arrangements (such as strategic alliances, joint ventures, sourcing and outsourcing agreements); however, efficiency refers to a necessary condition (Clark, 1921; Moran and Ghoshal, 1996) the company's operating margins reflect, while effectiveness corresponds to the company's ability to generate a sustainable growth in gains in the market (Gaertner and Ramnarayan, 1983). Ambler (2003) adds that companies rarely assess the full impact of their business action on key performance indicators (Barwise et al., 1989; Myers, 1999). Managers are often driven by efficiency indicators achieved by cost cutting, outsourcing activities, under-funding marketing or research and development, though these indicators aren't measures of effectiveness.

According to Mouzas (2006) the propensity to efficiency versus effectiveness reveals wasting new growth and value creation possibilities in the market. Profitability is important, but not the only driver of businesses; thus, investments in innovation, innovative marketing methods, HR and R\&D should be ingeniously scrutinized. On the other hand, the efficiency is a very relative indicator, which should be always compared to similar organizations. To continue, the difference between organic growth and structural growth should be always acknowledged in the corporate world. Profit is not always related to growth of companies, compared to competitors. Based on Mouzas (2006), efficiency calls for more financial expertise, control over operating margins and working capital requirements, whereas effectiveness calls for sound strategies of sustainable growth: it is related to the competitive environment, market dynamics, investments in innovation and differentiation.

Notwithstanding all the arguments in favour of effectiveness versus efficiency, companies can sustain a business growth if this is profitable. Thus, efficiency is a necessary, but not sufficient condition within a continuous process of development. The concept of economic efficiency is important for both theories and real practices, as it is impossible to get profit without financial resources, time and efforts accorded to an activity.

Economic efficiency could be tackled at a macro level, where it is often agreed that prices adjust in parallel to new information, as the stock market is highly or reasonably efficient. Osaze (2007), Grimblatt and Titman (2002) add the role of capital transactions and investment-associated costs. Guisso et al (2003), and Smitters and Wright (2000) emphasize that the willingness of organizations to invest, to take risk, to raise more funds will increase in line with the decreasing cost base; this also contributes to higher volumes in the market. To quickly react to the market changes and to be sustainable, organizations should be continuously involved in the market research along with lifelong improvement of their analysis expertise (Mackevičius et al, 2008).

The magnitude of profit and corporate profitability indexes were important figures to measure success of investments for many years. However, these figures do not show the efficiency of using available resources. Thus, the efficiency could be perceived as the ratio between results (income from products and/ or services) and the expended resources.

The concept of efficiency refers to circulation of a rational business process, driven by such motives as profit, cash flows and the speed of operations. In line with this reference, the term of efficiency might be associated with the value-added from activities. According to such argumentation, the value of any activity should be divided by its cost. It is added, that economic costs should be clearly distinguished from the whole cost base. Another element which should be added is the risk level obtained to get the desired result. As Sarulienè and Vilkas (2011) state, that the efficiency should help organization to operate, while efficiently using resources, cutting costs and increasing the value to its consumers or citizens.

The recent researches on organizational efficiency/ effectiveness, in particular related to the corporate world, 
are cantered on both economic impacts (profit margins, shareholders' value, revenue growth, and etc.) and social contributions (Corporate Social Responsibility, social innovation and etc.). Therefore, from the positive externalities and social image perspective, economic impacts are not sufficient to be sustainable and successful: without paying attention to social value-added, organizations (both private and public) might ruin reputation and competitive position in the market. For instance, Ribeiro-Soriano (2017) examined the role small business and entrepreneurship play in both economic and social development.

While referring to Carrasco-Monteagudo and Buendía-Martínez (2013), the author pointed out, that small businesses transform and develop communities, while entrepreneurs create ways to connect resources and growth across cultures, policy contexts, economic conditions and political situations that differ from a region to another. Thus, resolution of main economic and social challenges and the improved quality of life is considered as success and efficiency. Such development trends in business make it more compatible with civil service organizations, which also seek higher social value-added and sustainable performance in the longer run (see the Table 1).

Table 1. Communications Efficiency and Effectiveness in Lithuanian Civil Service Organizations, Compared to Private Sector*

\begin{tabular}{|c|c|c|c|c|c|c|c|c|c|c|c|c|c|c|}
\hline & & \multicolumn{12}{|c|}{ Communication Efficiency/ Effectiveness Dimensions } \\
\hline & & \multirow{2}{*}{ 莺 } & $\begin{array}{l}\text { Tech } \\
\text { Soci } \\
\text { Mec } \\
\text { Digit } \\
\text { Mar }\end{array}$ & ogies & \multicolumn{2}{|c|}{$\begin{array}{l}\text { Collaboration, } \\
\text { Networking, } \\
\text { Society } \\
\text { Engagement, } \\
\text { Community } \\
\text { Building }\end{array}$} & \multicolumn{2}{|c|}{$\begin{array}{l}\text { Competences, } \\
\text { Knowledge } \\
\text { Sharing }\end{array}$} & \multicolumn{2}{|c|}{$\begin{array}{l}\text { Innovation, } \\
\text { Creativity }\end{array}$} & \multicolumn{2}{|c|}{$\begin{array}{l}\text { Policy/ Strategy } \\
\text { Implementation } \\
\text { Sustainability, } \\
\text { Competitive } \\
\text { Advantages }\end{array}$} & \multicolumn{2}{|c|}{$\begin{array}{l}\text { Social } \\
\text { Impacts }\end{array}$} \\
\hline & & & B & CV & $\overline{\mathbf{B}}$ & CV & $\overline{\mathbf{B}}$ & CS & B & CS & $\overline{\mathbf{B}}$ & CS & B & CS \\
\hline \multirow{20}{*}{ 记 } & \multirow{5}{*}{ 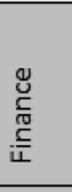 } & 5 & & & & & & & $\mathrm{x}$ & & & & & \\
\hline & & 4 & $\mathrm{x}$ & & & & & & & & $\frac{x}{x}$ & & & $\mathrm{x}$ \\
\hline & & 3 & & & $\mathrm{x}$ & $\mathrm{x}$ & $\mathrm{x}$ & $\mathrm{x}$ & & & & & $\mathrm{x}$ & \\
\hline & & 2 & & $\mathrm{x}$ & & & & & & $\mathrm{x}$ & & $\mathrm{x}$ & & \\
\hline & & 1 & & & & & & & & & & & & \\
\hline & \multirow{5}{*}{ 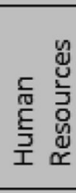 } & 5 & & & & & & & & & & & & \\
\hline & & 4 & & & & & & & $\mathrm{x}$ & & & & & $\mathrm{x}$ \\
\hline & & 3 & $\mathrm{x}$ & & $\underline{\mathrm{x}}$ & & $\mathrm{x}$ & & & & $\mathrm{x}$ & & $\mathrm{x}$ & \\
\hline & & 2 & & $\mathrm{x}$ & & $\mathrm{x}$ & & $\mathrm{x}$ & & $\mathrm{x}$ & & $\mathrm{x}$ & & \\
\hline & & 1 & & & & & & & & & & & & \\
\hline & \multirow{5}{*}{ 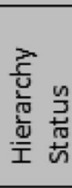 } & 5 & & & & & & & & & & & & \\
\hline & & 4 & $\mathrm{x}$ & & & & & & & & & & & \\
\hline & & 3 & & & $\mathrm{x}$ & & $\mathrm{x}$ & & $\mathrm{x}$ & & $\bar{x}$ & & $\mathrm{x}$ & $\mathrm{x}$ \\
\hline & & 2 & & $\mathrm{x}$ & & & & $\mathrm{x}$ & & $\mathrm{x}$ & & & & \\
\hline & & 1 & & & & $\mathrm{x}$ & & & & & & $\mathrm{x}$ & & \\
\hline & \multirow{5}{*}{ 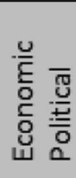 } & 5 & & & & & & & & & & & & \\
\hline & & 4 & & & & & & & & & & & & \\
\hline & & 3 & $\mathrm{x}$ & & $\underline{x}$ & & $\bar{x}$ & & $\mathrm{x}$ & & $\bar{x}$ & & $\mathrm{x}$ & \\
\hline & & 2 & & & & $\mathrm{x}$ & & $\mathrm{x}$ & & $\mathrm{x}$ & & & & $\mathrm{x}$ \\
\hline & & 1 & & x & & & & & & & & $x$ & & \\
\hline
\end{tabular}

*Where $\mathrm{B}=$ Business and CS $=$ Civil Service; the effects of factors are evaluated on the scale from 1 to 5; where 1 means negative effect on communication, and 5 stands for positive contribution, while 3 represents a neutral value.

Source. Prepared by the paper author, based on Le Bas and Laužikas (2010), Černikovaitė and Laužikas (2011), Vaiginienė et al (2014)

While examining civil service organizations, the majority of economical and finance-related effectiveness and efficiency indicators could be applied with some limitations, as combination of strategic targets and political priorities requires focusing more on social impacts as well as feasibility of political priorities, policies and strategies. While examining efficiency and social impact of public policies and third sector practices in Bulgaria, Zaimova et al (2012), deliver a conclusion that in order to strengthen the local capacity to implement and coordinate social policy, a strong public control and evaluation of the service quality should be established. 
Socials impacts refer to activities, such as supporting people in unequal position, promoting entrepreneurial solutions to social, cultural, health or environmental challenges, and many others.

Efficient and flexible communication (both vertically and horizontally) is part of organizational efficiency and effectiveness, and it should be achieved at different levels both inside and outside an organization; while external communication with society leads to higher transparency and sustainability as well as stronger social image of public administration organizations. Planning and execution of policies and strategies among public administration organizations should be very precise due to the lack of financial autonomy and limited resources.

To conclude, notwithstanding that the efficiency and effectiveness in public administration and business has been analysed separately for many decades, new emerging trends, such as networking, social innovation or the use of modern technologies require a holistic approach to effectiveness and efficiency from both public and private organizations: social image and strong strategic relationships with various stakeholders are necessary to create higher social value-added, while community building and society or consumer engagement are the main drivers of sustainable performance.

\section{Communication Efficiency in Civil Service Organizations}

Based on the study 'Comparing Leadership Challenges: Civil Service vs. Private Sector' in the USA (Ferguson et al, 2016), notwithstanding the specificity of public administration organizations (due to status, nature, orientation to political priorities, development trends and strategic targets, as well as limited financial autonomy), communication challenges in civil service organizations do not differ that much from private companies. Civil service organizations should improve their communication technologies because of the growing pressure from other stakeholders (private companies, universities, research centres, technology parks, and etc.). However, taking into account that civil service organizations often lack creativity and reword systems (as they need to generate bigger result in shorter time with limited financial resources), communication efficiency enhancement is particularly relevant and challenging.

Although scholars acknowledge that internal communication should be oriented to efficiency, creativity, motivation, flexibility, human relations, listening, quality, and many other aspects (Macnamara, 2016), modern communication technologies are not efficiently applied in both internal and external communication of civil service organizations.

External communication is centred on image, society engagement, social trust, sustainability, strategic targets and priorities, economic and social impacts as well as on key strategic partnerships (Hovland, 2005). However, if social trust between civil service organizations and citizens is damaged, it is difficult to regain reputation and build strong community; therefore, civil service organizations should build strong communication pillars, such as ethical codes, communication and behaviour guidelines, organization philosophy, creativity systems to survive and demonstrate sustainable performance. Moreover, civil service organizations in many efficiencydriven economies do not have communication plans during the time of change, which aggravates effects of uncertainty avoidance and fear of failure.

Transparency and social trust emerge as key factors in knowledge sharing and communication among politicians, civil servants and society; however, a relatively tall hierarchy and big power distance call for vertical communication models which diminish natural knowledge diffusion and community spirit. Therefore, diverse cross-departmental groups, informal and more horizontal communication processes inside and outside organizations (via modern technologies) are critical to countries which transform from efficiency to innovation category (GEM, 2018).

Simple online life-long learning tools, such as webinars or open-source learning platforms, social hubs for sharing good practices as well as projects connecting different-level civil servants and stakeholders could be useful to cut information asymmetry, raise motivation, speed-up communication, and optimize organisational 
performance (via synergy effects and cross-departmental co-operation). Such means help: improve social trust via community spirit and society engagement; diversify risks and enhance team-building competences inside civil service organizations. Moreover, it is necessary to improve communication at each level and each channel: if at one level civil servants are apathetic it will be immediately acknowledged by society and it could endanger the whole communication system later on. A constructive dialogue with less motivated employees should be established and the challenges presented within a communication plan or report (for instance, to identify and improve a stagnant organizational level via modern technologies; having no actions taken might paralyze the overall communication within an organization).

\section{Methodology}

The present research is based on semi-structured qualitative expert interviews with civil service specialists from Lithuanian public administration organizations with the majority of participants from various ministry departments. The first step of the research took place in Vilnius on the 1st and on the 5th December 2017 and was organized as part of interactive learning program "Communication Efficiency Factors within Strategic Change of Civil Service Organizations" among 40 specialists from various ministry departments of Lithuania. During the first day of the learning program, the main communication challenges were identified and the questionnaire for semi-structured expert interviews was developed: 20 experts, led by Prof. Laužikas, contributed to development of semi structured questionnaire.

The first two questions were related to communication specificity during the time of change (key responsible communicators, communication means and channels, communication type and techniques). Three additional questions referred to the possibility of improving communication efficiency and effectiveness via engaging society, building community and strengthening social image of civil service organizations, while paying a strong attention to modern technologies and social media (including the context of strategy development). Three questions were related to the role of Human Resource Management within communication processes (non-financial motivation, career choice, reasons for leaving an organization, or team-building capabilities). One question careered out the significance of innovation and creativity in communication; and one question was related to ethical and moral norms.

During the next stage, the second group of 20 civil servants completed the questionnaire, while drawing attention to the main organizational challenges and future opportunities to improve internal and external communication efficiency and effectiveness. Experts were coded, based on 3 criteria: the experience in civil service (less or more than 7 years), education background (business-related studies versus public administration), and their relation to internal and external communication (how much their work positions are communication-intensive).

Moreover, the experts' answers were coded, based on the communication improvement assumptions, which incorporated 7 aspects: the role of social media, modern technologies, partnerships, strategic targets, innovation culture, ethical and moral norms, hierarchy and power distance.

The third step of the research was held during the period 12th December 2017 - 12th January 2018, and was oriented to analysis of research results, comparison of primary and secondary data, as well as preparation of recommendations, which should be applied in Lithuanian Civil Service Organizations during the time of change.

\section{Research Results: The Role of Communication on Strategy Development among Lithuanian Civil Service Organization}

Communication efficiency and effectiveness within development and implementation of strategies and policies in Lithuanian civil service organizations (for instance, Innovation Strategy, long-term vision, mission, strategic targets and objectives, Social Responsibility, Human Resource Strategy, and many others) is centred on a set of functions and actions the experts try to apply in order to enhance their communication during the time 
of change: research (which is conducted while preparing strategic documents), monitoring, quality and risk management models, as well as communication plans during the time of change. Research results confirm that these documents along with efficiency criteria should be introduced to both employees and citizens and later on accompanied by progress and intermediary reports, reform plans and reshaped targets. Only G2C (Government to Citizens) model, based on the transparency and continuous interaction with society and other stakeholders, might lead to a better social image and sustainability.

Experts admit that engaging society and community building might require ingenious monitoring (strategic management competences) with more open communication approach and social trust, tolerance towards the fear of failure and constructive criticism, as well as knowledge sharing via modern technologies and innovative activities. Therefore, communication is shifting from a linear to transformational model, where it becomes more important to realign attitudes and perception in order to build the future electorate and engage society in decision-making.

Via simple communication methods, such as introducing the best citizens' ideas on a webpage, interactive hubs or mobile applications, it gets easier to engage bigger and more diverse audience; however, engagement is not enough: it is necessary to demonstrate capabilities to execute strategies via progress reports and co-operation with a vast spectrum of key strategic partners (which might be interesting to citizens thanks to innovative projects, reputation, and expertise). In the context of dissemination of strategic targets, it is also recommended to prepare and present social innovation and social responsibility reports, scientific publications along with performance improvement and sustainability recommendations as well as informal enhancement of competences in areas, such as econometrics, business models, brand innovation, digital marketing, talent development, creativity, and etc. Experts' interviews reveal that civil service specialists with business-related education background are more successful in adapting strategy dissemination techniques which are compulsory in the corporate world. Having a big percentage of intrapreneurs and citizens with the fear of failure in Lithuania (Singer et al, 2015), effective, efficient and explicit risk management models could free up creativity, innovation and leadership.

Answers to the first question illustrated, that during the time of change, the society and lower-level employees are not engaged in management of change: only two experts clearly describe the process of communication during the time of change as well as indicate the individuals or groups of individuals who should lead in communication among various stakeholders (politicians, ministers, heads of ministry departments, employees, and citizens). The experts' approach is more formal and conservative: they identify a specifically built initiative group, chancellor, head of HR department as the key communicators and intermediaries during the time of change; however, they do not emphasize neither horizontal communication inside their organization no employees or society engagement in decision-making process.

The "Top-Down" management model with a big power distance is emphasized by experts' along with their apathetic approach towards presentation of strategic goals, as only one expert emphasized the role of communication of strategy during the time of change, although his/ her suggested method was too conservative (via compulsory formal meetings for employees, emails or meetings in each department).

Communication in Lithuanian civil organizations is hierarchy-driven not only during the time of change; only two interrogated experts (with more solid experience in Civil Service) agreed that social media should be used to disseminate not only decisions but also motives and arguments why those decisions were made, to communicate to society the news regarding various projects, collect citizens' feedback and engage society while creating community spirit. Only one expert (having nearly 25 years of experience in civil service; with strong Business education background) emphasized the importance to engage employees in strategic decisionmaking from the perspective of non-financial motivation. Moreover, this expert emphasized the importance of attending strategy-related trainings in order to improve managerial competences, to provide the opportunity to go on business trips or participate in strategy development sessions.

From branding and social image point of you, only one expert emphasized integration of the change of 
organizational name into strategies as well as communication of a strategy inside and outside organizations through various process innovations (for instance, faster transfer of paper-format information to digital space; open-source innovation approaches, interactive social hubs, mobile technologies, and etc.).

Perception of innovation in a narrow way (not tackling process improvement or social innovation) emerges as a barrier to combination of innovation strategy with other strategies (HR, Marketing, Communication, and etc.). None among experts emphasized the potential to apply innovative management techniques, modern technologies and artificial intelligence in strategy-making, which could be explained by their limited knowledge in business, from education point of you, and uncertainty avoidance, from cultural and social norms point of you: conservative ways of strategic management are considered efficient and effective, because they are perceived as less risky, while risk management competences are rather modest.

Having no clear long-term strategy (one reform follows another reform without learning from mistakes), decision-makers do not link Human Resource dynamics and employee turnover to strategic targets, as only one expert tries to examine how exits of some employees affect the whole strategy of an organization. As it could be expected, this expert was motivated by clear strategic directions of the organization, its sustainability and feasibility of strategic targets. Moreover, two experts emphasized the role of teams' performance within a strategy along with the role of flexibility during the time of change: strategy becomes more dynamic and volatile; however, it should be oriented to long-term targets. Therefore, communication strategy and risk management techniques are critical.

Give a rather specific dynamics of strategy implementation, three experts are convinced that the potential of creative leaders is not fully explored: leaders should facilitate communication of strategic targets and efficiency criteria via "Bottom-Up" management approach, through horizontal communication and continuous ideas generation. One human resource strategies-related expert added that the main values, ethical and moral norms should be integrated into strategies via "Bottom-Up" approach, while strategic directions with clear values and philosophy should be communicated to the whole community via modern technologies.

Driven by G2C model, modern civil service organizations focus on engaging society and building stronger community; however, in parallel, they need to execute political priorities which are not always effective and sustainable. Taking into account, that they are in strategy implementation departments, they are more visible to society and, therefore, ought to be more accountable for their actions, oriented to political priorities. Although often civil servants do not fully support the political priorities, they need to be efficient and value-adding to society and other stakeholders. Ministries become as a communication channel between politicians and citizens: once the priorities are set, it is difficult to reshape them in order to react to global trends or sudden changes in the economy due to heavy bureaucratic mechanisms and lack of ministries' dynamism while revising the priorities.

Jeopardized by big power distance between politicians and civil service organizations, civil servants often work, based on priorities which are not encouraging and innovative, which often leads to the lack of commitment or negative social image of civil service organizations: it is very difficult to interact with society and engage or transform citizens' attitude having no motivation and knowledge regarding political priorities and expected impacts.

Within a rather tall hierarchy in Lithuanian civil service organizations, the majority of decisions and actions are made relying on bureaucratic procedures: communication is rather linear, vertical and more "Top-Down". For instance, within ministries, during the time of change, a team of heads of departments communicate to a new Minister their teams' expectations and actualities of each department and later on present the changes to employees: 6 experts, with no regards to their experience and education background, emphasized the role of heads of departments on communication during the time of change; 4 experts suppose that ministry chancellors, external communication specialists (PR) and Human Resource or Strategic Planning Departments should be involved in communication during the time of change, as these civil servants know better both political priorities and the context of their departments (including employees' expectations). 
Involving different level representatives should contribute to effective and efficient use of financial, intellectual, information, and human resources. Given a diverse experience and rich education background, all these representatives might help learn from past mistakes and make sustainable decisions, if society and all stakeholders are engaged in decision-making via modern technologies.

Scientific literature analysis draws attention to communication plans during the time of change at different governance levels, while having communication leaders appointed and right communication channels (with techniques and content of a message selected). Apart from asking 'Who', a question 'How' to communicate among politicians, civil servants and citizens should be examined. However, 9 experts recommend the use more vertical and traditional ways of "Top-Down" communication: via emails, meetings between ministers and departments' employees, Intranet and face-to-face communication. In spite of the importance of modern technologies, such as hubs, applications, software programs, experts suggest more liner communication style, while avoiding of interaction with society and neglecting community gathering. In addition to the focus on more traditional communication ways, there is vacant information 'Why' these priorities and changes are initiated and 'What' research they are based on; society and other stakeholders are not engaged in decision-making (which is not in line with the $\mathrm{G} 2 \mathrm{C}$ model), and communication is not transactional or transformational.

A more innovative approach is used in the context of social image strategy, as only three experts emphasized more traditional solutions, such as changing the name of organization, trainings in Lithuania and abroad (in order to enhance competences and improve motivation) or more flexible work schedules and distance work. As it was expected, such suggestions derived from older civil servants; other experts tried to find more innovative ways to improve the social image of their organizations. In light of limited financial motivation possibilities, two experts emphasized that scarce financial rewarding might also affect the social image of organizations due to employees' apathetic behaviour and out-dated technologies. Only one expert had a more conservative insight regarding shifting from information paper format to digital storage, as it should be step by step and not too radical. Conservative attitude and uncertainty avoidance are still felt in Lithuanian civil service organizations: 4 experts admitted that 'Innovative Ideas Banks' would be a great idea; however, it will trigger employees' opposition, while bureaucratic mechanism might be too heavy to make this tool smooth and efficient.

Tall hierarchy and strong power distance have direct and indirect impacts on intellectual capacity of organizations and Human Resource Management (including employees' satisfaction, their behaviour and turnover): 6 experts acknowledged that employees' resigning reasons are not formally identified and analysed; while based on their individual informal investigation, they acknowledge that the main reasons are related to bureaucracy, rules, rigidity, lack of autonomy and innovation, insufficient support from line managers, limited financial reward possibilities, and inefficient communication. On the other hand, many civil service organizations, particularly ministries, are attractive to younger specialists for diverse experience opportunities (for instance, project management), and the opportunity to use Public Administration education knowledge.

The more experienced experts emphasize social guarantees, status, stability, intellectual and friendly staff, as well as the future career opportunities. One experienced expert admitted that Human Resource Strategy was not present in ministry departments, which made human resource monitoring nearly impossible due to the lack of clear objectives and efficiency criteria. Such insight is supported by experts' position regarding teambuilding and team management: 6 experts had either negative or no opinion (due to insufficient information or lacking competences in this area) regarding team-building and teams' performance. No one emphasized how talented, innovative and/ or creative their teams are, while others had not enough information (which revealed fragmented and vertical communication in the context of Human Resource Management). Only one expert, related to Human Resource discipline, accentuated the role of creativity, enhancement of competences and application of non-financial motivation tools at teams' level.

Taking into consideration traditional bureaucratic models of communication in Lithuanian civil service organizations, it is not surprising, that only 3 experts emphasized the role of creative leaders, particularly in communication of strategic information (while making communication among various levels smoother and 
more informal, empowering creative leaders and encouraging interaction between leaders and specialists). One expert underlined the formula of efficient communication $(60 \%$ of leaders $+40 \%$ of specialists), which is in line with transformational communication style; however, no one emphasized the role of society engagement and community gathering in strategic management, which shows that Lithuanian civil servants are still not ready for the $\mathrm{G} 2 \mathrm{C}$ model. Two experts relied on rules and more traditional communication tools in strategic communication (emails and social media), while emphasizing the role of political priorities, which is more in line with linear "Top-Down" communication model.

The vertical communication model and formalism were also felt in the context of moral norms and ethical codes. Although the vast majority agreed that an ethical code is necessary, five experts had a very formal and legal approach to implementation of ethical codes, while emphasizing more rules rather than a holistic approach to innovation, creativity, transparency, sustainability, talent development, motivation, philosophy, values, social trust, value-added, interaction with society and etc. The rest of experts imagined efficient ethical codes as a guideline, even though internal and external communication was not strongly emphasized as an important aspect of ethical and moral norms. Tall hierarchy, rather big power distance, conservatively used modern technologies and still jeopardized social trust hold civil organizations back from introducing ethical codes and organizational philosophy, while forgetting the essence of ethical codes (it is more about ethics and inspiring organization than about rules and discipline).

All in all, the research results and scientific literature analysis drew attention to a set of factors that are necessary for communication effectiveness and efficiency among civil service organizations in order to be sustainable and reliable strategic partner among stakeholders and citizens (see Figure 1). On-going constant reforms in various policies create the feeling of functioning under the continuous time of change. Nevertheless, Lithuanian civil servants acknowledged the significance of society engagement and community gathering via a set of drivers, such as innovative approaches and new technologies, interactive continuous communication with citizens and bigger accountability and visibility in the society; but in order to be sustainable, public administration organizations should encourage creative leaders and experts with competences necessary for transformational communication in networks and big data-driven economies.

As it was stated by a couple of experts, G2C model is like "being a fish in an aquarium, visible to everyone" to all stakeholders; thus, civil servants face the necessity to communicate to stakeholders (including citizens) a vast spectrum of information related to political priorities, actions plans, expected outputs and even monitoring criteria: while engaging society and integrating citizens in decision-making and value-creation the undesirable effects of limited social trust could be mitigated and social image improved.

In light of modern technologies (including artificial intelligence, mobile technologies, digital hubs, and social medias), social trust is critical inside and outside an organization of tall-hierarchy; therefore, various ethical codes, behaviour guidelines or informal education could be of significant value during the time of change. Moreover, within the communication matrix (see Figure 1), all the impacts of communication efficiency and effectiveness (implementation of policy and strategy, social image, society engagement, and strong collaboration with stakeholders) were affected by transformational leadership with right competences and attitude. 




Fig. 1. The Matrix of Communication Efficiency and Effectiveness in Civil Service Organizations

Source: prepared by paper author, based on research results

\section{Conclusions}

In light of intelligence-driven management approaches and emerging new technologies, civil service organizations become closer to society; their philosophy should be in line with community values and principles, while transparency, accountability and sustainability should be improved via technologies, such as hubs, applications, software innovations, social media or video advertising. Civil service organizations become like huge "aquariums" where "fish" are visible to all stakeholders and, therefore, these pubic organizations should integrate society in strategy development and continuous innovation process.

However, rather conservative communication style, big power distance, tall hierarchies and heavy bureaucratic mechanisms jeopardize transformational communication, which should help engage employees, gather community, encourage creativity and create strong networks among stakeholders. Moreover, it is very difficult to reshape citizens' attitude and create community values when civil servants' performance is offset by the fear of failure, lack of competences, broken social trust, neglected modern technologies, and insufficient reward systems. All these factors form the environment, where 'Bottom-Top' approach and horizontal communication are not efficiently used.

Taking into account the lack of sustainability in performance of Lithuanian civil service organizations (due to a fragmental dialogue between politicians, different ministry departments and society or incapability to apply modern communication technologies in order to mitigate risk and information asymmetry) as well as insufficient engagement of society and employees in decision-making, diminishing communication enhancement might 
lead to the aggravated social trust issues, ruined reputation and a weak social image. Civil servants should learn to communicate during the time of continuous change and volatility. It is recommended to continuously monitor internal and external communication efficiency, prepare communication plans during the time of change, as well as apply non-financial motivation means within human resource strategies in order to become more open and technologically sophisticated.

Relying on the UK Government Communication Plan 2017/2018, it is possible to improve team-building capabilities and creativity enhancement system within tall hierarchies: horizontal communication technologies and project management techniques might be a good solution. Application of matrix management model and horizontal communication could help reach bigger synergy effect, cut power distance and build social trust. It is recommended to communicate with society every day and update citizens regarding all on-going activities (including challenges and risks).

Given rather limited cultural diversity, Lithuanian civil service organizations should apply informal learning methodologies (mentorship in the areas of digital marketing, mobile application, video advertising, econometrics, and etc.), employ foreign students, identify and support creative leaders, as well as engage society in innovation processes. It is time to start anticipating and planning communication during the time of change.

\section{References}

Abroms, C.L.; Maibach, E.W. 2008. The Effectiveness of Mass Communication to Change Public Behavior, Annual Revue of Public Health, 29: 219-234. www.annualreviews.org.

Ambler, T. 2003. Marketing: the trouble with finance, Business Strategy Review, 14(3): 54-62. https://doi.org/10.1111/1467-8616.00274

Barwise, P.; Marsh, P. R.; Wensley, R. 1989. Must finance and strategy clash? Harvard Business Review, pp. 85-90.

Bhatnagar, S. 2014. Public Service Delivery: Role of Information and Communication Technology in Improving Governance and Development Impact, ADB economics working paper series, No. 319, p. 36, ISSN: 1655-5252. https://www.adb.org/sites/default/files/ publication/31238/ewp-391.pdf

Borisov, A.; Narozhnaia, D.; Tarando, E.; Vorontsov, A.; Pruel, N.; Nikiforova, O. 2018. Destructive motivation of personnel: a case study of Russian commertcial companies, Entrepreneurship and Sustainability Issues, 6(1): 253-267. http://doi.org/10.9770/jesi.2018.6.1(16)

Carrasco-Monteagudo, I.; Buendía-Martínez, I. 2013. Corporate Social Responsibility: a Crossroad between Changing Values, Innovation and Internationalisation, European Journal of International Management, 7(3): 295-314. https://doi.org/10.1504/EJIM.2013.054327

Clark, F.E. 1921. Criteria of Marketing Efficiency, American Economic Review, 11(2): 214-231.

Darina Zaimova, D.; Genchev E.; Momchilov, H. 2012. Efficiency and Social Impact of Public Policies and Third Sector Practices in Bulgaria, International Review of Social Research, 2(2): 125-140. https://www.researchgate.net/publication/276431573_Efficiency_ and_Social_Impact_of_Public_Policies_and_Third_Sector_Practices_in_Bulgaria?ev=prf_high

Černikovaitė, M.E.; Laužikas, M. 2011. Issues of Innovations among Social Organizations in Lithuania, Social Research, 2(23): 388400

Ferguson, J.; Ronayne, P. and Rybacki, M. 2016. Comparing Leadership Challenges: Civil Service vs. Private Sector, Centre for Creative Leadership, White Paper Part 2 in a 3-Part Series, p. 20.

https://www.ccl.org/wp-content/uploads/2016/02/ComparingLeadershipChallenges.pdf.

French, S. 2017. Negotiating changes to Civil Service Performance Management Schemes: an analysis of the proposed Civil Service Performance Management Framework, p. 17. https://www.pcs.org.uk/sites/default/files/site_assets/resources/performance management/Performance\%20Management\%20-\%20Renegotiating\%20PM\%20Report\%202017.pdf

Gaertner, G.H.; Ramnarayan, S. 1983. Organizational Effectiveness: An Alternative Perspective, Academy of Management Review, 8(1). https://doi.org/10.5465/amr.1983.4287709.

Ghoshal, S.; Moran, P. 1996. Bad for practice: a critique of the transaction cost theory, Academy of Management Review, 21(1): 13-47.

Global Entrepreneurship Monitor 2018. GEM Report for 2017, ISBN-13: 978-1-939242-10-5. https://www.gemconsortium.org/report. 
Government Communication Service 2017. The UK Government Communication Plan: Our Priorities in 2017/2018, Crown Copyright, p. 44. https://gcs.civilservice.gov.uk/wp-content/uploads/2017/08/6.3149_CO_GCS-Comms-Plan_FINAL_WEB.pdf

Grinblatt, M.; Titman, Sh. 2002. Financial markets and corporate strategy. McGraw-Hill Irwin, p. 880: ISBN 0072294337, 9780072294330 .

Guisso, L.; Haliassos, M.; Jappelli, T. 2003. Equity Culture: Theory and Cross-Country Evidence. Economic Policy. pp. 123-170

Hovland, I. 2005. Successful Communication: A Toolkit for Researchers and Civil Society Organisations Research and Policy in Development Programme. Overseas Development Institute, ISBN 085003776 X, p. 78. https://www.odi.org/sites/odi.org.uk/files/odiassets/publications-opinion-files/192.pdf.

Husain, Z. 2013. Effective communication brings successful organizational change, The Business \& Management Review, 3(2): p. 8. http://www.abrmr.com/myfile/conference_proceedings/Con_Pro_12315/7-dubai13.pdf.

Kassa, C.B. 2011. The challenges and prospects of civil service reform and good governance in Ethiopia, African Journal of Public Affairs, 4(3): 11. https://repository.up.ac.za/bitstream/handle/2263/57803/Kassa_Challenges_2011.pdf?sequence=1\&isAllowed=y.

Le Bas, C.; Laužikas, M. 2010. Cooperation and partnership in the innovation process: the case of the Information technology sector in Lithuania, Intellectual Economics, 1(7): 7-17.

Laužikas, M.; Miliūtè, A. 2019. Transformational Communication via evolving ethical and moral norms of Lithuanian civil service organizations, Entrepreneurship and Sustainability, 6(4): 1750-1761. http://doi.org/10.9770/jesi.2019.6.4(14)

Lorincová, S.; Hitka, M.; Bajzíková, L'; Weberová, D. 2019. Are the motivational preferences of employees working in small enterprises in Slovakia changing in time, Entrepreneurship and Sustainability Issues, 6(4): 1618-1635. https://doi.org/10.9770/jesi.2019.6.4(5)

Luthra, A.; Dahiya, R. 2015. Effective Leadership is all about Communicating Effectively: Connecting Leadership and Communication, International Journal of Management \& Business Studies, 5(3): p. 6 ISSN: 2231-2463. https://www.mcgill.ca/engage/files/engage/ effective_leadership_is_all_about_communicating_effectively_luthra_dahiya_2015.pdf

Mackevičius, J.; Molienè, O.; Poškaitè, D. 2008. Bendrojo pardavimo pelningumo kompleksinès analizès metodika. Ekonomika, ISSN 1392-1258: http://etalpykla.lituanistikadb.lt/fedora/get/LT-LDB-0001:J.04 2008 1367177704178/DS.002.0.01.ARTIC.

Macnamara, J. 2016. Organizational listening: the missing essential in public communication. New York, NY: Peter Lang, p. 377. ISBN-13: 978-1433130526.

McEwan, D.; Ruissen, G.R.; Eys, M.E.; Zumbo, B.D.; Beauchamp, M.R. 2017. The Effectiveness of Teamwork Training on Teamwork Behaviors and Team Performance: a Systematic Review and Meta-Analysis of Controlled Interventions, PLoS ONE, 12(1). https://doi. org/10.1371/journal.pone.0169604.

Mouzas, S. 2006. Efficiency versus effectiveness in business networks, Journal of Business Research, 59(10-11): 1124-1132.

Myers, D. G. 1999. Close relationships and quality of life. In D. Kahneman, E. Diener, \& N. Schwarz (Eds.), Well-being: The foundations of hedonic psychology, pp. 374-391, New York, NY, US: Russell Sage Foundation.

Olufemi, T.M. 2012. Impact of computer use on the efficiency of civil service organisations in Ekiti State, Nigeria, European Journal of Business and Social Sciences, 1(2): 58 - 64. http://www.ejbss.com/recent.aspx.

Osaze, B. E. 2007. History, systems, practices, operations, procedures, investment techniques. Lagos, Nigeria: The Bookhouse Company, p. 416, ISBN: 978801920.

Paynton, S. T.; Hahn, L. K.; Lippert, L. 2016. Survey of Communication Study. Wikibooks, the Free Textbook Project. https:// en.wikibooks.org/wiki/Survey_of_Communication_Study.

Ribeiro-Soriano, D. 2017. Small business and entrepreneurship: their role in economic and social development, Journal Entrepreneurship \& Regional Development, 29(1-2): 1-3.

Sarulienè, A.; Vilkas, M. 2011. Efektyvumo ir lankstumo suderinimas tiekimo grandineje [Matching efficiency and flexibility in the supply chain], Ekonomika ir vadyba. 16, 907-915.

Shanga, S.M.; Wanga, Y.Y.; Wana, Q.Q.; Linb, F.; Zhoua, W.J. 2017. International Interventions to improve communication between nurses and physicians in the intensive care unit: an integrative literature review, Journal of Nursing Sciences, 5(1): 81-88. https://doi. org/10.1016/j.ijnss.2017.09.007. 
Shegenovna, I.A. 2014. Impact of the professionalism of civil service of Kazakhstan on political modernization, Procedia - Social and Behavioral Sciences, 143, 247 - 250. www.sciencedirect.com

Singer, S.; Amorós, J.E.; Arreola, D.M. 2015. Global Entrepreneurship Monitor Report for 2014. ISBN: 978-1-939242-05-1. https:// www.gemconsortium.org/report.

Smithers, A.; Wright, S. 2000. Valuing Wall Street. McGraw-Hill, p. 288, ISBN: 0071387838.

Vaiginienè, E.; Laužikas, M.; Miliūtè, A.; Varnienè, S.; Jakimavičius, T. 2014. Impacts of the fear of failure on the Dynamics of entrepreneurship in CEEC belonging to the EU since 2004, The Future of Entrepreneurship: 7th EMRBI Conference (ISI Proceedings), pp. 867-887 ISBN: 978-9963-711-27-7.

Vozab, D. 2012. Communication models of civil society organizations in Croatia, Observatorio, special issue 'Networked belonging and networks of belonging', p. 22: https://doi.org/10.15847/obsOBS000578

Zaimova, D.; Genchev, E.; Mochilov, H. 2012. Efficiency and Social Impact of Public Policies and Third Sector in Bulgaria, International Review of Social Research, 2(2): 125-140. http://www.irsr.eu/issue05/09_Zaimova_p125-140.pdf

\section{Biographical notes}

Dr. Mindaugas LAUŽIKAS is a Professor at Vilnius University Business School, Doctor of Economic Sciences, Director of GILE Experts (Malta). Lecturing experience in countries, such as Georgia, Sweden, France, Spain, Italy, Malta, Moldova, South Korea and Lithuania, is supported by publications in the field of knowledge economy, entrepreneurship and innovation. Research interests: national systems of innovation, entrepreneurship, knowledge and innovation management, innovation and human resource strategies.

Aistė MILIŪTÉ is a teacher/researcher at Vilniaus universiteto Verslo mokykla and entrepreneur within the mineral water and healthcare industries, a founder of AKVAVITA company.

ORCID ID: orcid.org/0000-0002-9667-3730 